\title{
The Marketing Concept in Islamic Perspective: A Literature Review
}

\author{
Mirza Tabrani ${ }^{*}$ and Marlizar $^{2}$ \\ ${ }^{1,2}$ Syiah Kuala University, Banda Aceh, Indonesia
}

\begin{abstract}
The objectives of this paper is to review some researches on marketing concept in Islamic perspective. The expected of this review is to provide benefits for related researches in the future. This study uses some review papers, empirical studies and books related to marketing concept in Islamic perspective. The analysis allows identifying interesting points for future research on the topic of marketing concept in Islamic perspective. This paper provides a better understanding on how Islamic perspective on marketing concept. This paper only reviewed concerned articles from Science Direct, Emerald Insight and books. The results of the review showed that the limited studies about the marketing concept in Islamic perspective (Islamic marketing concept). Result of this study is believed to give worth understanding about actual situation in this field of research. It proposed some notions that will stimulate more intensive researches in this field in the future.
\end{abstract}

Keywords: Islamic Perspective, Literature Review, Marketing Concept, Marketing Mix

\section{INTRODUCTION}

Islam Religion sees business activities as an important resource for someone to make a living during this process in accordance with Islamic teachings related to the proper ways to do business. Allah ordained Prophet Muhammad to be a successful businessman before his prophetic life (Antonio, 2007). Because Islam is the way of life, a code of conduct marketing should be guided by the Quran and Hadith, which are the two main sources of reference for Muslims in order to be succeed in life and hereafter.

Islamic perspective guarantees the important things in the field of global business for several reasons. First, Islam provides a framework that forms the moral and ethical behavior of the growing number of Muslim consumers worldwide. Second, an increasing number of Muslim population represent some of the most affluent consumers in the world. Third, there has been an increase in the level of foreign investment in Muslim countries in recent years. Fourth, there is a growing momentum towards the establishment of Muslim trading zone. Finally, the current political situation indicates that there seems to be the definite impetus towards greater Islamization of the countries that are predominantly Muslim in the form back to the application of Islamic law (Sharia) to all aspects of life (Saeed et al, 2001).

* Corresponding author. Email address: mirzatab@unsyiah.ac.id 
Islamic marketing (sharia marketing) are becoming interested issue among academicians, students, practitioners and consumers as demand for an interest in a particular issue become questionable among the countries of the Muslim minority and Muslim majority countries (Wilson, 2012). However, marketers play an important role in providing products and services to keep pace with customer expectations today. As a result, companies are expected to deliver their products and services in a way that is morally acceptable. Therefore, Islamic marketing provides a way for the implementation of the way marketing is morally acceptable. Islam is a comprehensive way of life that provides rules for everything including commercial activities (Arham, 2010).

Islamic marketing concept evolved over the development of Islamic economics. Some companies and sharia banks have applied this concept and have yielded positive results. Islamic marketing predicted to be growth and trusted by the people because of the values that correspond to what the community needs, namely honesty. In general, Islamic marketing is a business discipline strategy that directs the process of creation, bidding, and change the value from the initiator to its stakeholders that the entire process in accordance with the contract and the principles muamalah in Islam. This means that in the marketing of Islam, the whole process of the both creation process, the bidding process, and the process of change in value should not be contrary to Islamic law.

The purpose of this article is to explore the concept of marketing in the perspective of Islam. In order to have a good discussion, this article is organized as follows: the first section discusses the preliminary literature study why this needs to be done. The second section discusses the methodology used in conducting the study of this literature. The third section discusses the results and discussion and part four express a conclusion on this article.

\section{METHODOLOGY}

\section{Literature Search Methods}

The main literature conducted in Science Direct and Emerald Insight and other sources. Keywords used in the literature search are "marketing concept", or "Islamic perspective". Search by coating the next step is to check the reference lists of relevant articles were obtained. Then look for articles that are listed in the reference list of the main articles obtained with the help of search engine google.com. The literature search of the book was done by online and also textbooks.

\section{Inclusion and Exclusion Criteria}

This study is limited to literature published in ScienceDirect and Emerald Insight with the full text of articles are accessible available. Some titles of articles found that appeared as a keyword is the marketing concept and the Islamic perspective. Then after the study abstract and its contents, only a few articles that met the inclusion criteria (relevant topics of study literature). Therefore, the article is deemed not relevant were excluded from further review.

The Analysis Method 
This article is a review of the literature and not any empirical studies by examining primary sources related to the topics covered to extract and analyze the concept of marketing in the perspective of Islam. Therefore, the method used in this paper is an explorative descriptive method. Secondary data has been collected from relevant sources such diverse journals, textbooks, and others described in the narrative argumentative based on the theoretical study. There is no statistical or mathematical modeling methods are used to support the discussion of this article.

\section{RESULT AND DISCUSSION}

\section{Marketing definition literature from Conventional Perspective}

The literature on the definition of marketing from the perspective of conventional states marketing is an important aspect of any business in a highly competitive environment today. Marketing is the backbone of any organization. Marketing also something that affects every one of us in every moment of our lives. But the history of the creation of a marketing term, especially in the early 20th century. Since then Marketing has traveled far in the concept and definition. A different era presents concepts and definitions that differ from a different perspective. But in all of them there reflect the changing view of the phenomenon of marketing. It should also be developed so as to strengthen the role of marketing in organizations with alluring reality. If we look into the various definitions of marketing, we will find not a single definition that includes the total well-being of individuals, communities, society, and country or planet as a whole. It is important to understand marketing as dynamic and not static subjects (Cooke et al. 1992).

This discussion covers some alternative definitions of Marketing of literature known business that is recognized around the world, namely the definition of the American Marketing Association and the definition of renowned marketing experts that Phillip Kotler. The American Marketing Association (AMA) is the leading organization in the United States, representing the academic side of Marketing. This organization consists of and is mainly influenced by the people who teach marketing at the college level. From 1938, the AMA participates to unify the definition of marketing. In 1948, AMA defines marketing as follows:

Marketing is the performance of business activities directed to the event flow of goods and services from producer to consumer or user (AMA 1948).

In 1960, the definition was slightly changed to:

Marketing is the performance of business activities that direct the flow of goods and services from producers to consumers or users (AMA 1960).

In 1985, the AMA to change the definition of marketing into:

The process of planning and executing the conception, pricing, promotion, and distribution of ideas, goods, and services to create exchanges that satisfy the objectives of individuals and organizations (AMA 1985).

A new definition of marketing was developed by the AMA in 2004, namely: 
Marketing is an organizational function and a set of processes for creating, communicating, and delivering value to customers and for managing customer relationships in ways that benefit the organization and its stakeholders (AMA, 2004).

In 2007, introduced a new definition of marketing (Approved October 2007) by the AMA:

Marketing is the activity, set of institutions, and processes for creating, communicating, delivering, and exchanging offerings have value for customers, clients, partners, and society at large. (American Marketing Association 2007 in Yudi Fernando et al, 2012).

In 2013, a new definition of marketing introduced by AMA (Approved July 2013), namely:

Marketing is the activity, set of institutions, and processes for creating, communicating, delivering, and exchanging offerings have value for customers, clients, partners, and society at large.

Modern marketing expert Philip Kotler provides the latest definition of the marketing in 2004 was slightly modified as follows:

A social and managerial process by which individuals and groups obtain what they need and want through creating and exchange products and value with others (Kotler, 2004)

All these definitions have focused on the concept and philosophy of conventional marketing. According to that definition, marketing has been considered a special function or process of creating and exchanging a few supplies (goods and services) that meet customer and company goals. This broader definition has highlighted the secular and materialistic worldview that has attracted the maximum attention to the material aspects of human well-being and to maximize their wealth and want a sheer satisfaction.

This definition has given the idea that marketing is based on desire, not the necessity as companies seek profits and customers want satisfaction needs. So the company provides customer satisfaction and through which the company will realize a profit. The conventional marketing social views as the exchange relationship start with the basic idea that the behavior of some humans is planned, directed and they always want to find satisfaction; and individual acts to satisfy their wants and desires. Goods and services and commodities are the sources of satisfaction (Cooke et al. 1992). In addition, marketers also spent huge amounts for reform, modify, affect the desire and demand through promotional activities budget amount in excess of the total budget of a country's education sector has a greater impact to affect taste and consumer spending (Durning, 1992). It also creates a number of special wishes unwarranted, not related to the real needs of human beings through advertising in pursuit of goals that marketers maximize profits. The need still exists in the market; marketers only affect desire (Kotler et al. 2010).

The desire of customers for a product translates into demand only if they are willing and able to pay for it. So a product can meet the desire, but if there is no real demand, marketers will not be able to fulfill that desire profitably. The 
marketers practicing different marketing orientation to create demand. Marketing may affect the customer's desire to make the product attractive, appropriate, affordable and easily available. The modern world increasingly concerned with the process of providing products and services to people who want to satisfy man (Sharif, 1996). However, human desires are almost unlimited. On the other side of the basic human needs are limited, and the resources and products, which they call the goods and services, which would be enough to meet the basic human needs. It is possible to meet all basic human needs completely. Basic human needs as human beings are not increased.

The exchange is the heart of conventional marketing. Traditionally the exchange is regarded as the central concept of marketing (Bagozzi, 1975; Hunt, 1976). But in the process of this exchange, the customer is free to choose the type of goods and services; even there are no restrictions for suppliers. In conventional marketing, alcohol, magic, etc. also exchanged if it maximizes profits and utilities. No matter if the goods are harmful or beneficial to the buyer. If something has economic utility can be exchanged in the market. Pursuing the production and exchange of products and services are not guided by ethics (code of conduct) in the form of a real, though, the concept of social marketing, a little attention to social welfare has indicated.

\section{Define Marketing of Islamic Perspective}

Lack of significant efforts that have been done on the topic of Islamic marketing and limited to find the exact definition of a book or other source makes the marketing of Islam as a newly emerging field, and will take a long time to realize it as a great potential. More serious efforts are needed to do, because if handled the properly marketing of Islam will hold the key to creating a successful system to meet the needs of the Muslim population worldwide (Hussnain, 2011).

Islamic marketing analyzed and built on the philosophy that is based on a basic motif purpose of human creation. Islam set the overall life (QS3: 19 QS16: 52, QS98: 5, and QS110: 2). It means peace; at peace with yourself, peace with other human beings, peace in this life and peace in the hereafter and complete submission to God's will. In Islam, every aspect of human life must be in accordance with the will of God. In Islam, the marketing is not limited to the sale or imaging to benefit from the goods and services in all businesses. In Islam all activities and transactions considered as worship (QS2: 30). Islam is a way of life that is governed by rules that limit, which is explained and practiced by Prophet Muhammad SAW. Even nature and human behavior should not be against the Islamic faith, sharia, and Akhlaq. In addition to this, Islam set some rules of food meant to improve human welfare, also from Allah (QS5: 48).

Here are some definitions of marketing that quoted several articles about Islam marketing include:

Hussnain (2011) defines Islam as marketing:

The process of identification and implementation of value maximization strategy for the welfare of stakeholders in particular, and societies, in general, are governed by the guidelines given in the Quran and Sunnah. 
Alom \& Haque (2011) explains that Islam marketing can be defined as:

Processes and strategies (Hikmah) fulfillment through products and services that are Halal (Tayyibat) by mutual consent and welfare (Falah) of both parties that the buyer and seller for the purpose of achieving the material and spiritual welfare in this world and hereafter.

Abuznaid (2012) argues that Islam marketing can be defined as:

Wisdom satisfying customer needs through good conduct in providing products and services that are halal, healthy, holy and legitimate by mutual consent of sellers and buyers for the purpose of achieving the material and spiritual well-being in this world and hereafter and make consumers aware of it through the good behavior of ethical marketers and advertising.

There are some keywords/mentioned core aspects of this definition:

a. Wisdom (Hikmah)

In Islam the word Hikmah very close to the Strategy (Alom and Haque, 2011).

b. Needs

Islamic marketing is based on two basic requirements as mentioned in the Quran that the physiological needs of food, water and clothing and security needs (QS, 20: 118-119; QS17: 29) while conventional marketing based on a desire (Cooke et al.1992).

c. Muslim consumers

Is defined by consumption is not excessive, lifestyle and financial rules of the Muslim faith; they are far from homogeneous (Kearney, 2006). Muslim Consumers speak different languages, wear different styles of clothes and eat different food, for example in Turkey, Pakistan, Bangladesh, Kurdistan, Algeria, Morocco, Palestine and Saudi Arabia, the Gulf, etc. It is important to note that not all Arabs are Muslims and not all Muslims are Arabs.

d. Market

Muslim market complies with the principles of Sharia in all sectors. There is a religious viewpoint is received on this matter. For example, in Muslim countries the product non-halal or products that do not comply with Islamic principles that are sold in restaurants and hotels as alcohol and pork, some Muslim consumers do not have a problem eating in the hotel and restaurant for what they ordered and ate not contain pork or alcohol. While in many countries such as Malaysia, the restaurant must be free from pork before Muslim consumers will eat in it.

e. Good attitude

Good behavior is ethical behavior.

f. Halal (Tayyibat)

Products offered to contain virtue, pure, safe, lawful and profitable (QS 2; 172, QS 2: 168). The word "Tayyibat" is mentioned eighteen times in the Qur'an.

g. convenience

Fair and between buyers and sellers are free to choose without coercion (QS 4:29).

h. Welfare (Falah)

Success and well-being (QS 2: 201) and (Hadith). Sattar (1988), described Falah as the achievement of prosperity in this world and Hereafter. 


\section{i. Ethical advertising}

No action is misleading, deceptive or unfair on advertising (QS 3:77).

\section{The Basic Philosophy of Islamic Marketing}

The highest and most important concept in Islam is Tawheed or Oneness, the underlying message that must be understood from the concept of Tawheed is that, from an Islamic perspective, the dichotomy between science and religion is clearly not possible. (Alhabshi, 1987; Haneef, 1997). This is the most important concept that should be known by Muslims for the safety of life in this world and hereafter. Rice (2001) stated that the concept of Tawheed is the most important ingredient in the trade. Furthermore, according to Abu Sulayman (1998), the concept of Tawheed is vertical and horizontal relationships. A vertical relationship describes the relationship between man and his creator, while horizontal linkages depict human relationships under the law of God. The principle of Tawheed also requires Muslims believe that Allah is the sole architect of the universe and human beings because it is God's representative to manage this world and all its contents with how (Abu Sulayman, 1998; Badawi, 2002). In terms of marketing, Arham (2010) argues that justice can be applied to smooth the flow of goods, among others. By smoothing the flow of goods, the company will enable customers to meet their needs. The smooth flow of goods could prevent hoarding practices condemned by Islam. By eliminating the practice of hoarding, one has managed to show a person's actions of fraternity (both inter-human relations) to other people and also set a justice to the community. Because all people are basically the same, all customers have equal rights to obtain the desired product in order to meet their needs. Hoarding will raise prices and create injustice for those who cannot afford to buy a certain product they need.

\section{Islamic Marketing Characteristics}

In general, there are four characteristics that surround the marketing concept in Islam, the religious, ethical, realistic, and humanistic (Sula and Kartajaya, 2006). If one gives the four characteristics of the mind, one will get a good relationship between the five pillars of Islam and the implementation of it.

a. Religious, Islam marketers must fully believe that Islamic law is the supreme law should be used as guidelines only, perfect, and the source for all the goodness

b. Ethical, spiritual increase in the Islamic marketing will establish Islamic ethics in business transactions. One of the characteristics of Islamic marketers is full of ethical considerations

c. Realistically, Islamic marketers should not be so "rigid" in Islamic marketing practice, as long as it does not violate Islamic law. The content is more important than appearance. However, it should be noted that being realistic does not mean that in the case of "emergency", the Muslim marketer can do something that violates the principles of Islamic law.

d. Humanistic, Islam as other religions, came in order to teach people the values that can distinguish people from each other creatures that inhabit this world. Therefore, one should be able to keep out of a desire that such inhuman greed.

\section{Islamic Marketing Objectives}

The Islamic marketing objectives cannot be separated from the purpose of sharia. Based on the Islamic marketing philosophy, it is clear that the man was a messenger of God in this world. God entrusts the human being to control and 
manage the world according to His will (Khan, 1991; Haneef, 1997; Hassan and Lewis, 2007). This view is rather different from ours in conventional economics, as quoted by Haneef (1997: 45) as follows:

"This is of course, completely different from the" economic man, "that is modern is not obliged to consider the form of submission to Allah".

Therefore, the belief that God is giving should be used in all aspects of life, including marketing. Although in reality, different ways may be taken to take advantage of the belief that as long as they meet certain principles. The principles, according to Ahmad (1989: 26), are as follows:

"Agree with the principles of Islamic law or Sharia. Achieve economic and social goals of the Islamic civilization".

Arham (2010) argues that the goal of marketing is to bring Islam to the new world of marketing theory, in which the modern marketing theory associated with the teachings of Islam. Islam marketing should be able to take part in the realization of social justice.

\section{Marketing Mix in The Islamic Perspective}

In Islam any commercial activity governed by two principles. First, compliance with the order of Allah, second, empathy and compassion for God's creation which implies refraining from doing harm to others and thus prevent the spread of unethical practices (Niazi, 1996).

The marketing mix may vary according to consumer perception, consumer behavior, characteristics, culture, religion, politics, and habits. A sound ethical marketing-mix which states that freedom of decision making of customers should be protected from all the elements of coercion (Abul Hassan et al, 2008).

Saeed et al (2001), analyzing the Islamic perspective of the marketing mix to see the general aspects of the marketing mix are product, price, promotion, place and people.

According to Abuznaid (2012) states there is nine marketing mix from the viewpoint of Islam which are product, price, place, promotion, process, people, physical evidence, promise, and patience.

\section{Product}

The production process in Islam is a part of the worship of Allah (Al-Faruqi, 1992). This is very different compared to Western thought. In Islam, the production decision-making process is guided by the principles of legality, purity, existence, delivery, and the right determination (Al-Misri, 1991). These principles indicate that the product must:

1. Halal does not cause problems with thinking in any form, especially in a society (immoral).

2. The product must be wholly owned by owner

3. The products must be submitted after the sale and the product is not valid if it cannot be submitted as an example of selling fish in the river.

4. Goods are bought and sold must include the quantity and quality (Al-Ukhuwa, 1983 as cited in Abuznaid, 2012).

The main purpose of the production process is to provide, improve and meet basic human needs. Miller and Deiss (1966) showed that the main force behind ethical decision making suboptimal production is cost leadership strategy. On the 
contrary, Islam encourages the perspective of welfare and social approach rather than a decision based on the maximization of profit (Miller and Deiss, 1996). Product quality is very important in the ethics of Islam (QS 2: 172, 7).

Price

Price is the most flexible element of the marketing mix. It should be clear that in Islam takes into account the attention of shoppers is not less important than considering the attention to the seller. In Islam God is a price maker. Prophet Muhammad said in a hadith "Allah is the creator of the price; God gives wealth and hold it, and I hope to meet God if there is no complaint that I have been unfair to money or blood". However, when retailers and traders set the price of unfair, is important in Islam that the rulers (government) intervene for the sake of the population and to prohibit monopolies. Today, a lot of the fact that many businesses are purely profit-oriented, in the view of the Islamic government must intervene to protect the interests of citizens, taking into account that some customers are not aware of the price and can be fooled by marketers; Therefore, intervention is required. A role for the welfare of the community is to ensure that prices remain fair and just by limiting any ethical loopholes in the regulation of prices. All deviations are not ethical in prices is tantamount to injustice and sin. Pricing policy must be free from predatory pricing. Changes in prices should be consistent with changes in the quantity or quality of the product. Islam forbids false propaganda or publicity relating to price, demand, and supply. However, Islam does not forbid price control and manipulation to meet market needs. However, Islam prohibits extortion or making high profits at the expense of consumers (Koku, 2011) .To achieve positive results, there should be no hoarding, no price manipulation is justified and there are no restrictions on trade (Niazi, 1996).

In addition, "selling on credit should be documented and should be seen by others. Taking goods or goods of the buyer as security for payment recommended "(QS 2: 282). Therefore, the pricing policy in Islam should:

1. Do not cheat customers by giving the false impression that they are getting a bargain price (Shaw, 1996).

2. Prohibit get something too easily without hard work (Maisir), or receive benefits without working for it (Shaw, 1996).

3. Do not change the price without changing the quantity or quality of the product.

4. Not easy to deceive customers to benefit easily

5. There should be no discrimination between bidders and non-bidders to sell the same merchandise for different prices.

6. Prohibit false propaganda on the part of international marketers on demand supply position through the media.

7. Having control and manipulation of prices to meet the needs of this market as a result of the natural scarcity of supply is not prohibited.

8. Prohibit accumulation of any product to influence prices.

\section{Place (distribution channels)}

In Islam, marketing decisions pertaining to distribution is important. Decisions regarding the distribution of the product or service must consider that maximizing profits are not necessarily the most appropriate for the welfare of the community. According to the principles of Islam, distribution channels should not create burdens for the end consumer, in terms of higher prices and delays. Ethical irregularities in the distribution channel as causing unnecessary delays in the 
delivery of customer entice them to come back repeatedly and thus causing them unnecessary discomfort and are not allowed. Islam does not prohibit the institutions and representation of the channel as a go-between to facilitate the movement and acquisition functions. Unethical practices in the distribution of packaging could be weaker without adequate protection for the product; packaging inappropriate, and dangerous and toxic products have to be transported very carefully without any negligence. Harming people in the street, when transporting dangerous goods is equivalent to unfair marketing practices. Distributors must not use coercion; they also do not have to create a burden for the end customer in terms of higher prices and a delay (Al-Ukhuwa, 1938 in Abuznaid, 2012).. Facilitation of the delivery of goods and the acquisition of products by agencies are not prohibited in Islam. Finally, it should be emphasized that the ultimate goal of distribution in Islam is to create value and to provide the ethical satisfaction of products and services. Within the framework of Islamic ethics, however, the main purpose of distribution channels should create value and raised the standard of living by providing the ethical satisfaction of products and services (Saeed et al, 2001).

\section{Promotion}

Marketing communications about goods and services are not to deliberately deceive or mislead. In Islam, the seller and the buyer are responsible to God. Both have, to be honest, and fair in their marketing activities. In the promotion of products, there should be no room behavior sale to cover or hide defects in the product. All forms of false statements, praise the product in excess and connected to the quality they have, the charges baseless and false testimony is condemned (QS 33:58; QS58: 17-19). It is not allowed to praise the product or service redundant. Swear in the name of God in order to promote their products and persuade shoppers to buy goods not only allowed but also would revoke the blessing of God.

Give the wrong impression whatsoever to promote products is prohibited. In addition, all the things that have an element of coercion and are considered the unethical way of advertising is prohibited. False and misleading advertising and promotions were deceptive and manipulative should be avoided. The correct information that reveals the exact specifications e.g. quantity and quality should be disclosed. Stimulates lust, deceit, betrayal, theft or injustice is not allowed. Disclosure of all hidden flaws in a product and service is a must. Islam condemns all promotional manipulative behavior. Prophet Muhammad said, "The person who cheats is not one of our groups". In an effort to persuade people to buy their products, advertisers are prone to exploit ambiguity, concealing the fact by eliminating information that does not appeal to their products, exaggerating to make a claim that is not supported by evidence, and using her psychological entice customers with exciting requirements their emotional and unreasonable. Furthermore, Islamic ethics prohibits female stereotypes in advertising, the use of excessive fantasies, use of language and misconduct, and the use of women as objects to lure and attract customers (Erffmeyer et al, 1993; Beekun, 1981; Razzouk, 1993).

\section{People}


Employees are an integral part of the service process and play an important role in the marketing process. Employees have to be patient, honest, fair, and accountable. Islam emphasizes independent appraisal on the part of the customer; rational thinking when making decisions related to marketing is a prerequisite in Islamic law. It is the responsibility of the marketer to not use any form of coercion (Ikrah) by forcing someone to do something without his consent, and marketers should have the intellectual integrity and consumer awareness to ensure that consumers hard earned money and no waste (Abul Hassan, Chachi and Abdul Latiff, 2008).

In Islam, a marketer must be polite, gentle, honest, smiling. Marketers must be able to think rationally and care about the feelings and attitudes of customers. Marketers also need to have a good appearance. Women need to wear the hijab and to distance themselves from the actions excessive. Marketers' women should not wear tight clothing that can be seductive. The female staff is required to dress in clothing appropriate to the Muslim culture. Islam also ordered merchants to cease trading on Friday, especially on the eve of Friday prayers to finish Friday prayers. The Quran states: "O you who believe, if called upon to perform the Friday prayers, then you made haste remember Allah and leave your trading, which is better for you if only you know" (QS 62: 9).

Any unethical marketing practices do injustice, which, by definition, negates the concept of brotherhood and common humanity that make up the core vision of Islam (Saeed Ahmad and Mukhtar, 2001). Within the framework of Islam, marketers should show a sense of responsibility in four things: responsibility towards God, responsibility to society, the welfare of the marketer itself and environmental responsibility (Saeed et al, 2001). Violation of any of the above constitutes a violation of Islamic principles of individual marketers.

\section{Process}

The process is an element of the marketing mix and other elements known as the development of the marketing mix. The elements of the process including the procedures, mechanisms and flow of activities in which the services are provided. The process also means how the product will reach the end user. In fact, this process is critical of the marketing mix for customer satisfaction as waiting times, the information provided to customers, the efficiency in providing services, and the interaction of staff in the proper way, all this is important to maintain customer satisfaction. Customers are not interested to know in detail how the business is run by the seller. The important thing for the customer is a working system. In Islam, there are many Surahs in the Qur'an that describes the trade as a noble act and the desired activity. The main concern is to regulate the market to eliminate fraudulent transactions and exploitation of monopoly power and not remove the trade market (Uddin, 2003).

\section{Physical evidence}

Physical evidence is an element of implicit meaning the ability and the environment in which the service is delivered. Physical evidence both tangible goods and intangible experience of existing customers and the ability of the business to deliver customer satisfaction to potential customers can assist in the 
provision of communications services. Physical evidence is an important element of the services mix that allows consumers to make an assessment of the organization. Services cannot be felt before it is served. Selecting services can be the risk because buying something intangible. This uncertainty can be reduced to help potential customers to see what they would buy. Because intangibility these services, it is difficult for consumers to evaluate quality objectively. As a result, consumers often rely on real evidence surrounding services to assist them in evaluating them. Physical evidence can be categorized into three categories

1. Exterior amenities include exterior design, signposts, parking lots, landscaping, and the surrounding environment, such as building facilities overlooking the lake. In some Muslim countries such as bank buildings, shopping centers takes the form of Islamic architecture.

2. Interior amenities include elements such as interior design, equipment used to serve customers directly or used to run a business, direction, layout, air quality and temperature (Hoffman and Bateson, 2006). In Muslim countries will find a quoted verse of the Quran and Hadith, greeting placed on a wall. Mushalla facility or even a mosque for prayers.

3. Other things tangible, which is part of the company's physical evidence, including items such as business cards, stationary, invoices, reports, employee performance, uniform and brochures (Bitner, 1992).

Because of the unique characteristics of Islamic marketing, the customer will get a natural satisfaction of most aspects of products and services because it reflects a strong loyalty to the Islamic products and services. The atmosphere is courteous and facilities were not mixed to encourage customers to be more loyal.

\section{Promise}

The promise is the original elements of the Islamic marketing mix elements. Talking about the elements promise to speak of "management promises" that the change of the marketing mix to build relationships. An integral element of the marketing relationship approach is a "concept promises" very stressed by Henrik Calonius, which claimed responsibility for marketing not only make promises that they persuade the customer as a passive partner in the market to act in a certain way. A company that is busy with giving promises may attract new customers and build relationships first. However, if the promises are not kept, the relationship that has been built cannot be upgraded and maintained (Calonius, 1983 as cited in Grönroos, 2006). Fulfilling the promises given is the same importance as a means to achieve customer satisfaction, retention of the customer base and long-term profitability. It should be stressed that promises must be kept and maintained. Marketers should not give false promises. Allah has commanded the faithful to honor the promises. Al Quran states: "O ye who believe, fulfill it aqad (appointment) (QS 5: 1)," O ye who believe, why do not you say something that you do? It is most hateful in the sight of Allah that you say anything that you do not (QS 61: 2-3), "O ye who believe! Fear Allah and be with those who are true (QS 9: 119). The importance of keeping the promise has been emphasized in the Sunnah. Prophet Muhammad said in his Hadith: "The signs of the hypocrite are three, namely: when he said a lie, when he reneged on promises, if believed it treason" (Hadith narrated by Bukhari Muslim as cited in Abdul Baqi, 2012). From an Islamic perspective, every promise made to customers must be preserved and respected. 


\section{Patience}

Patience is another element of the Islamic marketing mix. This element is very important in the service industry. Islam teaches people to be patient in serving customers. Patience is the key characteristic of good communication. Because of the importance of patience, Allah mentions in particular verse about patience in the Qur'an. Allah has commanded us to be patient Quran states "... Allah loves those who are patient" (QS 3: 146), "..... and be patient. Allah is with those who patiently persevere" (QS 8: 46)," Be patient, there...not patience, but with the help of God ... "(QS 16: 127), Allah is indeed rewarded believers to be patient, Quran states: "the properties are good it was not granted, but to those who are patient and do not confer but to those who have the great fortune" (QS 41: 35).

Table 1 Marketing Mix in Islamic Marketing

\begin{tabular}{|c|c|c|}
\hline No & Element & \begin{tabular}{|l} 
Islamic ethics \\
\end{tabular} \\
\hline \multirow[t]{10}{*}{1} & Product & o Compliance with Sharia \\
\hline & & o Do not use God's name in the brands and labels \\
\hline & & ○ Halal (Holy and lawful) \\
\hline & & ○ Accurate Labeling \\
\hline & & o here are no weak packaging \\
\hline & & o Do no harm to customer \\
\hline & & ○ No thought is dull \\
\hline & & O No products obsolete \\
\hline & & ○ Value Resistance \\
\hline & & ○ The environmental impact \\
\hline \multirow[t]{8}{*}{2} & Price & O Fear of Allah (Allah is a price setter) \\
\hline & & o Fair and There should be no cheating \\
\hline & & o Approach public welfare \\
\hline & & o Maximizing profits simply not a priority. \\
\hline & & O No price is justified \\
\hline & & o There is no price manipulation \\
\hline & & O No predatory prices \\
\hline & & $\circ$ There are no feed prices \\
\hline \multirow[t]{6}{*}{3} & Place & o Do not harm others streets \\
\hline & & ○ No delay unnecessary \\
\hline & & $\circ$ There is no compulsion \\
\hline & & ○ The distribution channel is not encumbering customers \\
\hline & & o Closure during Friday prayers \\
\hline & & O Avoid suspicious location \\
\hline \multirow[t]{11}{*}{4} & Promotion & o Complying Sharia \\
\hline & & o Women should not be used to attract or lure customers \\
\hline & & ○ No use suggestive language and behavior \\
\hline & & $\begin{array}{l}\text { There is no concealment of facts and information (Disclosure } \\
\text { errors and defects) }\end{array}$ \\
\hline & & ○ No promotion of manipulative behavior \\
\hline & & o No sexual appeal \\
\hline & & $\circ$ There is no oath in the name of God \\
\hline & & O Attribute not excessive \\
\hline & & o No ad was misleading \\
\hline & & o There is no fraud \\
\hline & & ○ No obscene ads \\
\hline \multirow[t]{3}{*}{5} & People & o Complying with Islamic law (Shari'a) \\
\hline & & o Polite, friendly \\
\hline & & o Offers smile, Honest \\
\hline
\end{tabular}




\begin{tabular}{|c|c|c|}
\hline No & Element & $\begin{array}{ll}\text { Islamic ethics } \\
\end{array}$ \\
\hline & & $\begin{array}{l}\text { C Clad and look good } \\
\circ \text { There is no fraud } \\
\circ \text { Do not harm customers } \\
\circ \text { There is no compulsion } \\
\circ \text { Respect for private property } \\
\circ \text { Avoid actions and behavior suspicious }\end{array}$ \\
\hline 6 & Process & 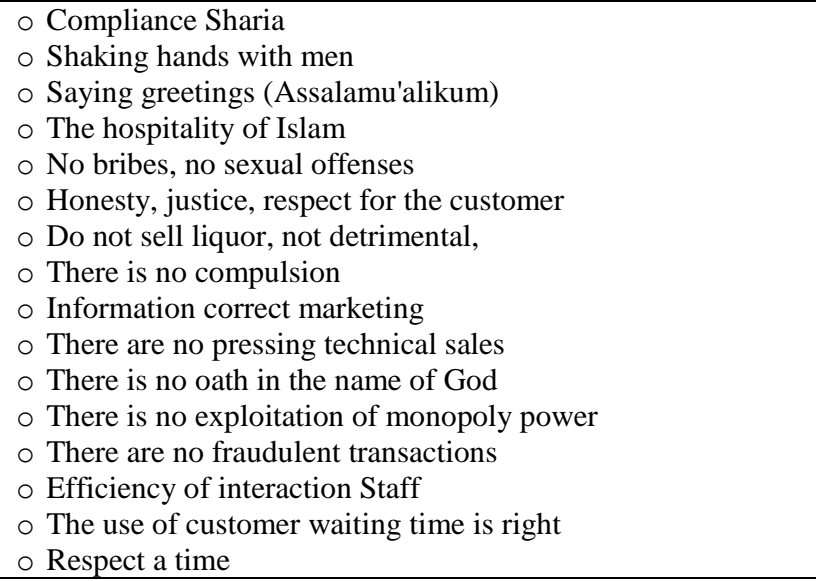 \\
\hline 7 & $\begin{array}{l}\text { Physical } \\
\text { Evidence }\end{array}$ & $\begin{array}{l}\circ \text { Obeying the law } \\
\circ \text { There are no gambling halls } \\
\circ \text { There is a mosque in the company } \\
\circ \text { Islamic Architecture } \\
\text { Emblazoned o Quranic verses, Hadith and greeting on the wall } \\
\circ \text { Image founders (not mandatory) } \\
\circ \text { Documentation and testimony credits } \\
\text { - Taking the goods as collateral for credit payments }\end{array}$ \\
\hline 8 & Promise & $\begin{array}{l}\text { O Complying with Islamic law (Sharia) } \\
\circ \text { Respect pledge } \\
\circ \text { No false promises } \\
\circ \text { Respect a time } \\
\circ \text { Manage Appointments } \\
\text { ○ Relationship marketing } \\
\text { ○ Good communication } \\
\circ \text { Persuasion Passive } \\
\end{array}$ \\
\hline 9 & Patience & $\begin{array}{l}\circ \text { Complying with Islamic law (Sharia) } \\
\circ \text { Be patient with a wide range of customers } \\
\circ \text { Good communication skills } \\
\circ \text { Listening to customers } \\
\circ \text { Be helpful }\end{array}$ \\
\hline
\end{tabular}
Source: Abuznaid, 2012

\section{The Main Difference Between Islamic Marketing and Conventional Marketing}

Adnan (2013) states that difficult to find a contradiction between the Islamic and conventional definition of marketing. The only difference is the guarantee Halal according to Islamic law for goods and services. There are several different views about the difference between Islam marketing with conventional marketing. However, based on literature review has been conducted, the authors explore and identify at least there are some things that can differentiate between sharia 
marketing and conventional marketing, for more details can be seen in the following table:

Table 2 The differences between Islamic marketing and conventional marketing

\begin{tabular}{clll}
\hline No & \multicolumn{1}{c}{ Aspect } & \multicolumn{1}{c}{ Islamic Marketing } & \multicolumn{1}{c}{ Conventional Marketing } \\
\hline 1 & $\begin{array}{l}\text { The scope of } \\
\text { the definition }\end{array}$ & $\begin{array}{l}\text { Broader Maximizes } \\
\text { the value of the } \\
\text { welfare of } \\
\text { stakeholders and the } \\
\text { general public in } \\
\text { accordance with the } \\
\text { Quran and Hadith. }\end{array}$ & $\begin{array}{l}\text { Narrow and does not include } \\
\text { the total well-being of } \\
\text { individuals, communities and } \\
\text { the country as a whole }\end{array}$ \\
\hline 2 & $\begin{array}{l}\text { The concept } \\
\text { and basic } \\
\text { philosophy }\end{array}$ & $\begin{array}{l}\text { Ethics and Islamic } \\
\text { values in its } \\
\text { activities }\end{array}$ & $\begin{array}{l}\text { Non-value and not based on } \\
\text { the deity in its activities }\end{array}$ \\
\hline 3 & $\begin{array}{l}\text { Marketers } \\
\text { ethics }\end{array}$ & $\begin{array}{l}\text { Tied to Islamic } \\
\text { ethical }\end{array}$ & $\begin{array}{l}\text { Adaptive, situational and } \\
\text { conditional }\end{array}$ \\
\hline 4 & $\begin{array}{l}\text { The approach } \\
\text { to consumer }\end{array}$ & $\begin{array}{l}\text { Business partners is } \\
\text { aligned }\end{array}$ & Target sales \\
\hline 5 & $\begin{array}{l}\text { The } \\
\text { perspective } \\
\text { of } \\
\text { competitors }\end{array}$ & $\begin{array}{l}\text { Business partners } \\
\text { and not an opponent } \\
\text { to be defeated }\end{array}$ & An opponent to be defeated \\
\hline 6 & $\begin{array}{l}\text { Marketing } \\
\text { objectives }\end{array}$ & $\begin{array}{l}\text { Not only material } \\
\text { gains alone but also } \\
\text { spiritual gain }\end{array}$ & $\begin{array}{l}\text { Advantage through customer } \\
\text { satisfaction }\end{array}$ \\
\hline
\end{tabular}

\section{CONCUSION}

From the above discussion, it can be said that the Islamic perspective to marketing, it can be used as a marketing tool and construct new knowledge called "Islamic marketing" as another way to understand the science of marketing. Islamic approach to the business is regulated by two sources, namely the Qur'an and the Hadith of the Prophet shaped guide how Islam entire life. The practice of Islam is based on the divinity and faith, and does not recognize the separation between the earthly dimension and hereafter; it is different with western contemporary marketing practices based on profit maximization. According to the Islamic perspective, activities are based on the goal of satisfying the material alone will inhibit rational thinking people and will make them into slaves of a marketing company. Islam respects freedom and offers free mankind from all shackles of slavery, including from international marketers. As for the fundamental differences between Islam marketing with conventional marketing is situated on the ethics and values of Islam in any marketing activities based on the Qur'an and the Hadith.

The purpose of this article is only reviewing the literature theory of marketing concept in the Islamic perspective; this article describes several perspectives from previous literature and not to formulate a comprehensive new model of marketing Islam. Although the field of marketing Islam has laid down some clear theory, further research is still needed to understand Islam in a comprehensive marketing. 
Some of the future research have been identified and the chance to do such research literature review about the marketing practice in Islamic law, Islamic rent and sale, the Islamic concept of Halal market and branding Islam and other topics. In addition, empirical research to find out the perceptions and attitudes of non-Muslim customers in choosing products and services of Islamic Halal, perceptions and attitudes towards marketers Muslim women in an Islamic society. Future research should not be limited to Muslim consumers' comparison with non-Muslims in Muslim countries, but more widely to explore the Muslim minority which describes the role of Islam and the adaptation of consumption culture brand strategy for different Muslim consumers.

\section{References}

Al-Qur'an dan terjemahnya (2005). Mujamma'Al Malik Fahd Li Thiba'at Al Mush-HafAsy-Syarif Madinah Munawwarah: Komplek Percetakan AlQur'an Raja Fahd, Kerajaan Arab Saudi.

Abusulayman, A.A. (1998). The theory of the economics of Islam. Journal of Islamic Economics, 6(1), 79-122.

Abul Hassan Chachi, A. \& Abdul Latiff, S. (2008). Islamic Marketing Ethics and its Impact on Customer Satisfaction in The Islamic Banking Industry. JKAU: Islamic Economy, 21(1), 27-46.

Abuznaid, S. (2012). Islamic marketing: addressing the Muslim market. An-Najah University Journal for Research-Humanities, 26(6), 1473-1503.

Abdul Baqi, Muhamad Fuad. (2012). Terjemahan Al-Lu'lu'uwalmarjan (kumpulan hadits shahih bukhari muslim). Semarang: PT. Pustaka Riski Putra.

Adnan, Ahmad Azrin. (2013). Theoretical Framework for Islamic Marketing: Do We Need a New Paradigm? International Journal of Business and Social Science, 4(7), 157-165.

Al-Faruqi, I. R. (1992). Al Tawhid: Its Implications for Thought and Life. Herndon, VA: International Institute of Islamic Thought.

Alom, Md. Mahabub \& Haque, Md. Shariful. (2011). Marketing: An Islamic Perspective. World Journal of Social Sciences, 1(3), 71-81.

Alhabshi, S. O. (1987). The role of ethics in economics and business. Journal of Islamic Economics, 1(1), 1-15.

Al-Faruki, Ismail Raji. (1992). Al Tawhid: its implication for thought and life (IIIT. Kuala Lumpur).

Al-Misri, Ahmad Ibn Naqub. (1991). The Reminiscences of the Traveler: A Classical Manual of Islamic Sacred Law. Trans.by NoahHa Mim Keller (Modern Printing Press. Abu Dhabi).

American Marketing Association. (1960). Marketing Definitions: A glossary of marketing terms, AMA, Chicago.

American Marketing Association. (2016). Marketing Definitions: https

Antonio, M. S. (2007). Muhammad SAW: The Super Leader Super Manager, Prophetic Leadership and Management Centre, Jakarta

Arham, M. (2010). Islamic Perspectives on Marketing. Journal of Islamic Marketing, 1(2), 149-164.

Badawi, Jamal A. (2002). Islamic Worldview: Prime Motive for Development. Humanomics, 18(3), 3-25. 
Bagozzi, RP. (1975). Marketing as Exchange. Journal of Marketing, 39, 32-9.

Beekun, R.A. (1981). Islamic Business Ethics. The Islamic Institute of Islamic Thought. Human Development Series 2.

Bitner, M. (1992). Services capes; the impact of physical surrounding on customers and employees. Journal of Marketing, 56(2), 57-71.

Chartered Institute of Marketing. (2015). Marketing and the 7Ps: A brief summary of marketing and how it work.http://www.cim.co.uk/

Cooke, EF, Rayburn, JM \& Abercrombie, CL. (1992). The history of marketing thought as reflected in the definitions of marketing. Journal of Marketing Theory and Practice, Fall, 10-20.

Durning, Alan. (1992). How Much is Enough. New York: Norton, p.122.

Grönroos, Christian. (2006). On Defining Marketing: Finding New Roadmap For Marketing. Marketing Theory, 6(4), 395-417.

Erffmeyer, R.C. Al-Khatib, J.A. \& Hair, Jr. (1983). Sales Training Practices: A Cross -National Comparison. International Marketing Review, 10(1), 4559.

Hassan, M.K. and Lewis, M.K. (2007). Ends and Means in Islamic Banking and Finance. Review of Islamic Economics, 11, 5-27.

Haneef, M.A.M. (1997). Islam, The Islamic Worldview, and Islamic Economics. IIUM Journal of Economics and Management, 5(1), 39-65.

Hoffman, K. \& Bateson, H. (2006). Service Marketing: Concepts. Strategies and Cases. Thompson South-Western Publishing.

Hunt, SD. (1976). The Nature and Scope of Marketing. Journal of Marketing, 40, 17-28.

Hussnain, Syed Ali. (2011). What Is Islamic Marketing. Global Journal of Management and Business Research, 11(11), Version 1, 101-103.

Kearney, A.T. (2006). Addressing The Muslim Market. Fortune.

KoKu, P. S. (2011). Natural Market Segment: Religion and Identity-the Case of Zongos in Ghana. Journal of Islamic Marketing, 2(2), 177-185.

Kotler, Philip. (2004). Manajemen Pemasaran, Edisi Milenium, PT. Indeks Kelompok Gramedia, Jakarta.

Kotler, P., Bowen, J.T. \& Makens, J.C. (2010). Marketing For Hospitality and Tourism, (5th ed.). Boston: Pearson.

Kotler, P. (2010). Marketing Management (millennium ed.). Upper Saddle River: Prentice Hall International.

Khan, M.A. (1987). Methodology of Islamic economics. Journal of Islamic Economics, 1(1), 17-33.

Khan, M.A. (1991). The future of Islamic Economics. Futures, 23(3), 248-261.

Miller, A. \& Deiss, G.G. (1996). Strategic Management. New York: McGraw Hill.

Niazi, Liaquat Ali Khan. (1996). Islamic Law of Contract (ResearchCell. Dyal Sing Trust Library) Lahore.

Razzouk, N. and Al-khatib, J. (1993). The Nature of Television Advertising in Saudi Arabia: Content analysis and Marketing Implications. Journal of International Consumer Marketing, 6(2), 65-90.

Rice, G. (2001). Islamic ethics and the implications for business. Journal of Business Ethics, 18(4), 345-58.

Sattar, Zaidi (1988). The Ethics of Profit in the Islamic Economic System: A Socioeconomic Analysis. The Islamic Quarterly: A Review of Islamic Culture, 32(2), 69-76. 
Saeed, Mohammad, et al (2001). International Marketing Ethics from an Islamic Perspectives: A value Maximization Approach. Journal of Business Ethics, 32, 127-142.

Sula, M.S. and Kartajaya, H. (2006). Shariah Marketing. Bandung: Mizan.

Sharif M. Raihan. (1996). Guideline to Islamic Economics (Nature, Concepts and Principles), Bangladesh Institute of Islamic thought, Dhaka, Bangladesh.

Shaw, S. A. (1996). Business Ethics. (Wad Worth Publishing Company. Belmont.

Uddin, S. J. (2003). Understanding the Framework of Islam in an Era of Globalization; A review, Business Ethics: A European Review, 12(1), 2333.

Wilson, J. (2012). The New Wave of Transformational Islamic Marketing: Reflections and Definitions. Journal of Islamic Marketing, 3(1), 5-11.

Yudi Fernando Norizan Mat Saad Mahmod Sabri Haron. (2012). New Marketing Definition: A Future Agenda For Low Cost Carrier Airlines in Indonesia. Business Strategy Series, 13(1), $31-40$. 